\title{
Pengembangan Materi Ajar Sejarah Bermuatan Lokal Pada SMAN Di Sumatera Barat
}

\author{
Wahidul Basri \\ wahidulsejarahunp@gmail.com \\ Universitas Negeri Padang
}

\section{Abstract}

This research departs from the fact that indonesian history learning nuanced local content is still rarely applied by history teachers in West Sumatra. Meanwhile, KTSP and K-13 applied in various schools in Indonesia requires applying local content into learning. Why is this happening and what is the solution? Here's the main question in this study. The purpose of this research is to produce a local-loaded Indonesian History Book of West Sumatra that can be used for the study of Indonesian History in high school. This research was designed for two years, the first year of researching the needs of teachers regarding indonesian history materials nuanced local content in accordance with the curriculum 2013. Furthermore, make a prototype book of Indonesian History that is charged locally in West Sumatra. The second year, produced a product in the form of Indonesian History Textbooks containing local history of West Sumatra. This research is R\&D by following the working steps formulated by Plomp. Based on the research measures that have been implemented, in the first year has been produced Prototype Indonesian History Book containing Local History of West Sumatra for learning in high school. In the second year, validity, practicality and effectiveness are conducted. Validity test results show that The Indonesian History Book containing Local History of West Sumatra for high school learning is valid, the practicality test results show practical to use, while the results of effectiveness tests show effectively applied in historical learning. Based on the results of the tests conducted, it can be concluded that the Indonesian History Textbook is charged with Local History of West Sumatra for high school learning, valid, practical and effective to be used as a supplement to the learning materials of Indonesian History.

Keywords: development, history material, learning, local history, textbooks.

\section{Abstrak}

Penelitian ini berangkat dari kenyataan bahwa pembelajaran Sejarah Indonesia yang bernuansa muatan lokal masih jarang diterapkan oleh guru sejarah di Sumatera Barat. Sementara itu KTSP dan K-13 yang diterapkan di berbagai sekolah di Indonesia mengharuskan memasukan materi muatan lokal ke dalam pembelajaran. Tujuan penelitian ini adalah mengembangkan Buku Sejarah Indonesia bermuatan lokal Sumatera Barat yang dapat digunakan untuk pembelajaran Sejarah Indonesia di SMA. Penelitian ini menggunakan metode R\&D dengan mengikuti langkah-langkah kerja yang dirumuskan Plomp. Berdasarkan langkah-langkah penelitian yang telah dilaksanakan, pada tahun pertama telah dihasilkan Prototype Buku Sejarah Indonesia bermuatan 
Wahidul Basri

Pengembangan Materi Ajar Sejarah Bermuatan Lokal

Pada SMAN Di Sumatera Barat

Sejarah Lokal Sumatera Barat untuk pembelajaran di SMA. Pada tahun kedua dilakukan uji validitas, praktikalitas dan efektifitas. Hasil uji validitas menunjukkan bahwa Buku Sejarah Indonesia bermuatan Sejarah Lokal Sumatera Barat untuk pembelajaran di SMA valid, uji praktikalitas hasilnya menunjukkan praktis untuk digunakan, sementara hasil uji efektifitas menunjukkan efektif diterapkan dalam pembelajaran sejarah. Berdasarkan hasil pengujian yang dilakukan, maka dapat disimpulkan bahwa Buku Teks Sejarah Indonesia bermuatan Sejarah Lokal Sumatera Barat untuk pembelajaran di SMA, valid, praktis dan efektif untuk digunakan sebagai suplemen materi pembelajaran Sejarah Indonesia.

Kata kunci: pengembangan, materi sejarah, pembelajaran, sejarah lokal, buku teks.

(c) (7) (2) This work is licensed under the Creative Commons Attribution-ShareAlike 4.0 International License

\section{Pendahuluan}

Transfer ilmu biasanya dilakukan guru dalam proses pembelajaran, baik di dalam, maupun di luar kelas (Utomo, 2019). Oleh sebab itu sebelum proses pembelajaran dilakukan seorang guru harus melakukan perencanaan pengajaran yang sangat bergantung kepada kompetensi seorang guru menyangkut tiga hal pokok (Jufri, 2016). Pertama, tentang apa yang akan diajarkan. Kedua, bagaimana cara mengajarkan sesuatu sehingga bisa mencapai tujuannya. Ketiga, mengetahui bahwa yang diajarkan itu dapat mencapai sasarannya (PPS UNY, 2002, hal 1). Persoalan pertama berkaitan dengan tujuan pembelajaran dan materi yang akan diajarkan. Sementara, persoalan kedua menyangkut strategi, model, metode, dan alat yang akan digunakan. Selanjutnya persoalan ketiga menyangkut evaluasi yang dilakukan untuk mengukur pencapain materi.

Untuk mencapai tujuan di atas, seorang guru yang profesional harus membuat persiapan mengajar secara baik dan maksimal sebelum melakukan proses pembelajaran. Dalam persiapan ini terkandung tujuan mengajar, pokok bahasan apa yang diajarkan, metode mengajar, bahan pelajaran, alat peraga dan teknik evaluasi yang akan diberikan (Hamalik, 2010). Semua hal tersebut harus benar-benar dipersiapkan secara matang agar dapat meningkatkan kelancaran proses pembelajaran.

Melalui persiapan yang matang sebelum mengajar, proses pembelajaran akan dapat berjalan dengan lancar tanpa hambatan yang berarti. Pembelajaran 
menjadi lebih terkonsentrasi, dan siswa lebih mudah mencerna informasi atau materi pembelajaran. Guru merupakan salah satu komponen manusia dalam proses pengajaran, dan mereka berperan dalam usaha membentuk sumber daya manusia yang potensial di bidang pembangunan (Anrianti, R., Suri, S., \& Melay, 2013). Oleh karena itu, guru merupakan salah satu unsur penting yang harus berperan serta secara aktif dan menempati kedudukan sebagai tenaga profesional, sesuai dengan tuntutan masyarakat yang semakin berkembang (Kunandar, 2011).

Dalam menyusun persiapan mengajar, berupa silabus dan Rencana Pelaksanaan Pembelajaran (RPP), seorang guru harus berpedoman pada materi atau kurikulum yang digunakan (Salirawati, 2005). Materi pelajaran merupakan hal yang sangat menentukan dalam keberhasilan pembelajaran. Selain materi, guru juga harus berpedoman pada kurikulum yang dijalankan, karena itulah yang akan jadi tolak ukur keberhasilan proses pembelajaran secara keseluruhan (Subiyakto \& Akmal, 2020). Di dalam kurikulum biasanya terdapat indikator yang dapat dikembangkan menjadi tema-tema pembelajaran. Tema-tema itu mengacu pada kompetensi-kompetensi (Kompetensi Inti dan Kompetensi Dasar) tertentu yang sudah dirancang sedemikian rupa. Tugas guru adalah mengemas dan mengembangkan semua komponen itu ke dalam Rencana Pembelajaran yang efektif dan tepat guna.

Pembelajaran sejarah bersifat unik dan khas, karena sejarah berorientasi kepada masa lalu. Dalam arti kata, sejarah mempelajari peristiwa dan kejadiankejadian masa lalu. Lebih penting lagi, sejarah merupakan dialog antara masa lalu, masa kini, dan masa depan (Soejatmoko, 1984). Oleh sebab itu tujuan pembelajaran sejarah tidak hanya pada transfer pengetahuan, tetapi juga pada nilai-nilai (afektif) yang berguna pada kehidupan hari ini. Di samping itu, secara pragmatik pengajaran sejarah juga bertujuan untuk meningkatkan kemampuan berpikir inkuiri siswa, serta mengaplikasikannya untuk kehidupan hari ini (I Gde, 1991).

Secara substansi, materi sejarah juga mengandung tiga hal yang esensial, yakni fakta, konsep, dan kausalitas (Zulfa, Z., \& Husnita, 2015). Fakta merupakan pernyataan-pernyataan dari gambaran masa lampau, konsep sebagai bentuk pengelompokkan fakta sejenis, dan kausalitas sebagai hubungan sebab akibat dalam fakta dan peristiwa sejarah (Rochmiatun, 2013). Oleh sebab itu cara mengajarkan materi sejarah mestinya juga bersifat khusus, dan hanya bisa dilakukan oleh orang-orang yang mengerti sejarah, atau guruguru sejarah yang profesional. 
Wahidul Basri

Pengembangan Materi Ajar Sejarah Bermuatan Lokal

Pada SMAN Di Sumatera Barat

Dalam pembelajaran sejarah, guru harus dapat mendekatkan siswa dengan objeknya, dalam hal ini tentu saja peristiwa yang dipelajarinya. Contoh; fakta harus ditemukan dalam fenomena di sekitar mereka. Konsep dibangun dan dikembangkan berdasarkan realitas masa lalu, dan realitas ini mengelilinginya. Dengan cara ini, akan lebih mudah bagi siswa untuk mempelajari dan menjelaskan peristiwa atau peristiwa masa lalu. Maka dalam hal ini peran dari materi sejarah dengan muatan lokal sangat penting diberikan untuk mendukung materi dasar dalam kurikulum.

Dimasukkannya unsur muatan lokal (Casanova et al., 2018) dalam kurikulum pada hakikatnya tidak lepas dari realitas bahwa Indonesia memiliki keberagaman dalam segala hal, terlebih untuk adat istiadat, kesenian, tata cara, tata krama pergaulan, bahasa dan pola-pola kehidupan yang turuntemurun dari nenek moyang bangsa Indonesia (Hardi, 2017). Semua itu mesti menjadi rujukan penting bagi anak didik agar tidak kehilangan ciri khas dan jati dirinya. Maka sangat perlu menjaga kekhasan ini. Upaya yang dapat dilakukan adalah melalui penambahan materi sejarah dengan muatan lokal, mulai dari tingkat sekolah dasar, sekolah menengah, bahkan hingga ke perguruan tinggi oleh guru/dosen.

Sejarah lokal berasal dari dua kata yaitu: sejarah (history) dan lokal (local). sejarah lokal adalah sikap/pandangan hidup dan ilmu pengetahuan serta berbagai macam strategi kehidupan yang berwujud aktivitas yang dilakukan oleh masyarakat dalam pemenuhan kebutuhan mereka dari masa ke masa (Wijayanti, 2017). Sejarah lokal pada dasarnya dapat dipandang sebagai landasan bagi pembentukan jati diri. Disamping hal tersebut muatan materi lokal bisa menjadi jembatan yang menghubungkan masa lalu dan saat ini, generasi lalu dan generasi sekarang, untuk mempersiapkan masa mendatang dan generasi yang akan datang (Fajarini, 2014). Oleh sebab itu diperlukan adanya usaha memperdalam dan lebih memahami kearifan lokal. Dan salah satu upaya yang dapat dilakukan yaitu melalui pendidikan (formal, non formal, dan informal).

Dalam proses pembelajaran, mata pelajaran harus dapat mendorong siswa agar dapat mengenal diri dan lingkungan disekitarnya. Memperdalam dan menanamkan nilai-nilai sejarah lokal melalui berbagai proses pembelajaran merupakan salah satu bagian dari usaha untuk membangun identitas sebuah bangsa dan dapat dijadikan sebagai salah satu sarana dalam menyeleksi pengaruh budaya asing yang masuk (Suyitno, 2012).

Dalam sejarah lokal terkandung nilai yang dapat dikembangkan dalam pembentukan karakter dan identitas suatu bangsa. Sejarah lokal bangsa 
Indonesia merupakan kemampuan penyerapan kebudayaan asing yang datang secara selektif, artinya disesuaikan dengan suasana dan kondisi setempat (Fajarini, 2014). Dengan demikian sejarah lokal adalah nilai-nilai yang berlaku dalam suatu masyarakat sesuai dengan kondisi setempat. Nilai-nilai yang diyakini kebenarannya dan menjadi acuan dalam bertingkah-laku sehari-hari

Dengan muatan lokal guru dapat mengoptimalkan pengetahuan dan pemahaman sejarah siswa, serta meningkatkan kesadaran sejarahnya (Atmaja, 2017). Sebab pembelajaran sejarah dapat diperkaya dengan berbagai peristiwa sejarah yang terjadi di sekitar siswa. Muatan lokal juga akan membuat pelajaran sejarah lebih menarik bagi siswa karena fakta-faktanya sangat dekat dengan mereka, sehingga memudahkan mereka untuk mempelajarinya . Kondisi nyata disekitar siswa dapat digunakan oleh guru sebagai cara untuk menggambarkan dan mengantarkan suatu peristiwa sejarah serta memahami berbagai isu sosial yang ada dalam masyarakat. Penelitian Nana Supriatna telah membuktikan bahwa muatan lokal sangat efektif dalam meningkatkan kemampuan siswa dalam memahami berbagai isu sosial yang ada di sekitarnya (Supriatna, 2005).

Demikian pentingnya muatan lokal ini, hingga di dalam pengembangan kurikulum di Indonesia sejak masa lalu hingga dicanangkannya Kurikulum 2013 (K-13) pemerintah selalu mempertimbangkan keberadaannya. Keberadaan muatan lokal dalam kurikulum telah diatur dalam Surat Keputusan Menteri Pendidikan dan Kebudayaan Republik Indonesia Nomor 0412/U/1987 tanggal 11 Juli 1987. Kemudian pelaksanaannya mulai dijabarkan berdasarkan Keputusan Direktur Jenderal Pendidikan Dasar dan Menengah Nomor 173/C/Kep/M/87 tertanggal 7 Oktober tahun 1987. Menurut surat keputusan tersebut yang dimaksud dengan muatan lokal adalah program pendidikan yang isi dan media penyampaiannya dikaitkan dengan lingkungan alam dan lingkungan budaya serta kebutuhan daerah dan wajib dipelajari oleh murid di daerah tersebut.

Sementara dalam K-13 muatan lokal diatur dalam Peraturan Menteri (Permen) No. 79 Tahun 2014. Dalam Permen tersebut dikatakan bahwa muatan lokal merupakan bahan kajian atau mata pelajaran pada satuan pendidikan (SD, SMP/MTs, dan SMA/MA) yang berisi muatan dan proses pembelajaran tentang potensi dan keunikan lokal yang dimaksudkan untuk membentuk pemahaman peserta didik terhadap keunggulan dan kearifan di daerah tempat tinggalnya (Permen Diknas No.79 Tahun 2014, pasal 1 dan 2). Secara materi muatan lokal boleh menjadi mata pelajaran tersendiri atau diintegrasikan ke dalam mata pelajaran tertentu, seperti sejarah. 
Pembelajaran sejarah lokal merupakan salah satu mata pelajaran yang memiliki pengaruh dalam pengembangan tujuan pendidikan nasional (Naim, 2013). Oleh karena itu, pembelajaran sejarah yang berwawasan muatan lokal tetap menjadi perhatian penting dan prioritas utama bagi guru sejarah dalam pelaksanaan pembelajaran, karena akan lebih memudahkan bagi siswa dalam memahami realitas masa lalu bangsanya. Akan tetapi kenyataan yang dijumpai di lapangan para guru sejarah di tingkat Sekolah Menengah Atas (SMA) di Sumatera Barat masih jarang memanfaatkan muatan lokal di dalam proses pembelajaran sejarah (Hardi, 2017). Mereka masih terjebak dalam pemahaman materi sejarah secara leterlek sebagaimana yang tertulis dalam buku teks resmi (buku babon), tanpa ada kreatifitas untuk mengembangkannya.

Dari pengalaman tim peneliti sendiri ketika berhubungan dengan guruguru sejarah SMA di Sumatera Barat, baik dalam kegiatan MGMP (Musyawarah Guru Mata pelajaran), seminar dan diskusi-diskusi ilmiah, ataupun pembimbingan Praktek Lapangan Kependidikan (PLK) mahasiswa, juga dijumpai kenyataan yang demikian. Para guru sejarah belum mampu mengembangkan muatan lokal ke dalam berbagai Pokok Bahasan (Tema) yang disampaikan kepada siswa. Persoalan ini tentunya menarik untuk ditelusuri lebih jauh. Apakah ini disebabkan karena ketidakmampuan mereka untuk mengolah materi sejarah yang bersifat lokal untuk diintegrasikan ke dalam pokok bahasan yang sudah ditentukan dalam kurikulum nasional. Oleh sebab itu perlu dilakukan penyusunan dan pengembangan bahan ajar sejarah yang bersifat lokal yang kompeten dan holistik yang dapat menampung kebutuhan pembelajaran di sekolah. Hal ini tentunya harus dilakukan secara bersamasama dengan para guru yang berada di lapangan.

Penelitian ini penting dilakukan mengingat sampai saat ini pengajaran sejarah di sekolah-sekolah tetap mendapat sorotan luas dari berbagai kalangan dalam masyarakat. Berbagai suara miring ditujukan kepada bidang studi sejarah, seperti membosankan, bersifat faktual, terlalu tekstual, serta kurang inovatif. Semua tudingan itu mengarah pada satu hal ialah kegagalan pengajaran sejarah di berbagai tingkat pendidikan. Hal itu jelas amat merisaukan sebab semangat perubahan yang berkembang dalam era Reformasi belum mampu merubah wajah pengajaran sejarah di sekolah-sekolah.

Padahal sejak masa lalu selalu didengung-dengungkan bahwa pengajaran sejarah memiliki peran besar dalam membentuk karakter bangsa, serta pembinaan integritas bangsa. Sebagaimana dinyatakan oleh Sartono Kartodirdjo bahwa sejarah adalah sebagai sarana pembentuk identitas diri suatu bangsa (Kompas 5 Oktober 1990, hal IV). Bahkan di masa depan peran 
pengajaran sejarah menjadi semakin penting karena dikaitkan dengan arus globalisasi dan informasi, yang dalam banyak hal telah menghilangkan sentimen-sentimen nasional dan lokal. Dengan kondisi pengajaran sejarah yang memprihatinkan seperti di atas jelas hal itu amat tidak menguntungkan dalam kehidupan berbangsa dan bernegara. Tujuan penelitian ini adalah mengembangkan Buku Sejarah Indonesia bermuatan lokal Sumatera Barat yang dapat digunakan untuk pembelajaran Sejarah Indonesia di SMA

\section{Metode Penelitian}

Penelitian ini adalah penelitian pengembangan dengan model prosedural (Sakkab, 2002). Penelitian pengembangan atau Research and Development (R\&D) adalah rangkaian proses atau langkah-langkah dalam rangka mengembangkan suatu produk baru atau menyempurnakan produk yang telah ada agar dapat dipertanggungjawabkan (Trianto, 2010). Produk yang akan dikembangkan adalah Buku Teks Sejarah Indonesia yang bermuatan sejarah lokal Sumatera Barat, dengan kategori valid, praktis dan efektif.

Buku Teks Sejarah Indonesia bermuatan sejarah lokal Sumatera Barat yang akan dikembangkan menggunakan model pengembangan Plomp. Rochmad (2012) mengemukakan bahwa model Plomp lebih luwes dan fleksibel dibanding model lainnya, karena setiap langkahnya memuat kegiatan pengembangan yang dapat disesuaikan dengan karakteristik penelitian. Fasefase dalam model penelitian pengembangan yang dikemukakan Plomp meliputi fase investigasi awal (preliminary investigation), fase desain (design), fase realisasi/konstruksi (realization/ construction), fase tes, evaluasi, dan revisi (test, evaluation, and revision) serta pengoperasionalan.

\section{Hasil dan Pembahasan Penelitian}

Buku teks pembelajaran yang baik ditentukan dari kualitas produk hasil pengembangan. Nieveen (2013:29) menjelaskan bahwa kualitas buku teks pembelajaran ditentukan oleh beberapa kriteria, yaitu validity (kesahihan), practicalitiy (kepraktisan) dan effectiveness (keefektifan) (Asri, 2017; Dhita, A. N., Asmi, A. R., \& Yunani, 2021). Oleh sebab itu kualitas buku teks pembelajaran ditentukan dari validitas, praktikalitas dan efektivitas komponen buku tersebut.

1. Validitas Buku Teks Sejarah Indonesia Bermuatan Sejarah Lokal Sumatera Barat untuk pembelajaran Sejarah Indonesia di SMA 
Wahidul Basri

Pengembangan Materi Ajar Sejarah Bermuatan Lokal

Pada SMAN Di Sumatera Barat

(Wiyanarti, E., Supriatna, N., \& Winarti, 2020)

Berdasarkan hasil analisis data validitas, Buku Teks Sejarah Indonesia Bermuatan Sejarah Lokal Sumatera Barat untuk pembelajaran Sejarah Indonesia di SMA memperoleh rata-rata $\mathrm{k}$ 0,84 dengan kategori sangat valid. Buku teks pembelajaran dikatakan valid bila semua komponen buku telah terpenuhi.

Komponen buku teks yang harus dipenuhi dalam kelayakan isi, kebahasaan, penyajian, kegrafikaan. Seperti yang tercantum dalam Peraturan Pemerintahan Nomor 19 Tahun 2005 (Lembaran Negara Republik Indonesia Tahun 2005 Nomor 41, Tambahan Lembaran Negara Nomor 4496) Pasal 43 ayat (5) bahwa Komponen buku teks yang pertama adalah kelayakan isi, isi buku teks harus layak dan pantas serta sesuai dengan tingkatan pendidikan peserta didik yang akan menggunakan. Isi nya harus didukung oleh sumber yang benar dan memiliki data yang cukup. Buku Teks Sejarah Indonesia Bermuatan Sejarah Lokal Sumatera Barat yang dikembangkan untuk pembelajaran Sejarah Indonesia di SMA berasal dari sumber yang cukup dan data yang sesuai dengan kebutuhan siswa SMA.

Kebahasaan merupakan komponen kedua untuk menentukan kevalidan buku teks. Bahasa yang benar akan membuat si pembaca mudah memahami isi buku. Penyajian yang menarik dan kegrafikaan yang bagus akan membuat siswa SMA berminat untuk membaca buku Sejarah Indonesia yang bermuatan sejarah lokal Sumatera Barat. Buku Teks Sejarah Indonesia Bermuatan Sejarah Lokal Sumatera Barat yang dikembangkan untuk pembelajaran Sejarah Indonesia di SMA memenuhi keempat komponen buku teks yang baik sehingga validator merekomendasi untuk digunakan.

2. Praktikalitas Buku Teks Sejarah Indonesia Bermuatan Sejarah Lokal Sumatera Barat untuk pembelajaran Sejarah Indonesia di SMA

Praktikalitas Buku Teks Sejarah Indonesia Bermuatan Sejarah Lokal Sumatera Barat untuk pembelajaran Sejarah Indonesia di SMA ditentukan dari tiga hal yaitu, terpakainya buku teks dalam pembelajaran, respons guru sebagai praktisi dalam menggunakan buku teks, serta response siswa. Buku Teks Sejarah Indonesia Bermuatan Sejarah Lokal Sumatera Barat untuk pembelajaran Sejarah Indonesia di SMA. Buku teks pembelajaran dinyatakan praktis bila mudah digunakan. Kemudahan penggunaan dilihat dari keterpakaian buku tersebut. Hasil uji keterpakaian menunjukkan bahwa Buku Teks Sejarah Indonesia Bermuatan Sejarah Lokal Sumatera Barat untuk pembelajaran Sejarah Indonesia di SMA dapat dilaksanakan dengan semua kriteria terpakai. 
Selanjutnya praktikalitas Buku Teks Sejarah Indonesia Bermuatan Sejarah Lokal Sumatera Barat untuk pembelajaran Sejarah Indonesia di SMA dilihat dari respons guru. Respons guru terhadap buku teks dilihat dari kemudahan penggunaan buku. Guru menyatakan Buku Teks Sejarah Indonesia Bermuatan Sejarah Lokal Sumatera Barat untuk pembelajaran Sejarah Indonesia di SMA mudah digunakan. Berdasarkan diskusi dengan guru sehabis pembelajaran terungkap bahwa buku teks tersebut sangat membantu mereka dalam mengajar Sejarah Indonesia.

Selain kemudahan implementasi, praktikalitas juga dilihat dari manfaat buku teks tersebut untuk pembelajaran sejarah di SMA. Buku teks ini bermanfaat untuk melatih siswa melakukan pengamatan; melakukan prediksi dan inferensi; mengumpulkan data dan informasi, mengetahui dan memahami peristiwa sejarah yang ada di lingkungan mereka, melahirkan semangat kebangsaan dan rela berkorban. Oleh sebab itu, Nieveen Nieveen di SMA bermanfaat untuk melahirkan sikap kebangsaan.

Praktikalitas selanjutnya ditentukan dari keterpakaian Buku Teks Sejarah Indonesia Bermuatan Sejarah Lokal Sumatera Barat untuk pembelajaran Sejarah Indonesia di SMA (Nafi'ah, U., Ayundasari, L., Suprapta, B., Sayono, J., \& Hasan, 2021). Buku tersebut membantu guru dalam membimbing siswa melakukan pengamatan; membantu guru dalam membimbing siswa merumuskan masalah; membantu guru dalam membimbing siswa merumuskan hipotesis dalam pembelajaran, melakukan prediksi dan inferensi; membantu guru dalam membimbing siswa mengumpulkan data dan informasi untuk membuktikan hipotesis, prediksi dan inferensi yang diajukan (Purwanto, 2021).

Selain tanggapan siswa terhadap Buku Teks tersebut, pada angket juga ditanyakan tentang peran guru dalam pembelajaran (Yamin, 2021). Sesuai dengan respons siswa terbukti bahwa guru dapat menjalankan peran sebagai fasilitator, dan pembimbing selama pembelajaran berlangsung. Sesuai pendapat Nieveen (dalam Plomp, 2010: 29), bahwa tingkat kepraktisan dilihat dari pendapat praktisi. Buku pembelajaran disimpulkan praktis jika (1) praktisi menyatakan buku dapat digunakan di lapangan dan (2) tingkat keterpakaian buku pembelajaran termasuk kategori "baik". Berdasarkan hal tersebut berarti Buku Teks Sejarah Indonesia Bermuatan Sejarah Lokal Sumatera Barat untuk pembelajaran Sejarah Indonesia di SMA memenuhi aspek kepraktisan.

3. Efektivitas Buku Teks Sejarah Indonesia Bermuatan Sejarah Lokal Sumatera Barat untuk pembelajaran Sejarah Indonesia di SMA 
Wahidul Basri

Pengembangan Materi Ajar Sejarah Bermuatan Lokal

Pada SMAN Di Sumatera Barat

Efektivitas buku teks pembelajaran (Tinnisa, 2021) dilihat dari kompetensi yang dimiliki siswa. Buku Teks Sejarah Indonesia Bermuatan Sejarah Lokal Sumatera Barat untuk pembelajaran Sejarah Indonesia di SMA dikembangkan sebagai salah satu materi ajar yang bermuatan lokal Sumatera Barat sehingga salah satu parameter efektivitas buku teks adalah materi yang mudah dipahami siswa dalam pembelajaran. Pemahaman siswa terhadap materi dipengaruhi oleh aktivitas mereka dalam belajar secara individu, aktivitas dalam kelompok serta aktivitas sikap ilmiah (Trisanti, D. Y., \& Andayani, 2021). Hasil analisis data menunjukkan bahwa aktivitas siswa dalam ketiga aspek yang diamati berada dalam kategori sangat aktif.

Aktivitas belajar merupakan kegiatan-kegiatan yang dilakukan oleh siswa yang berhubungan dengan materi pembelajaran. Tidak ada belajar bila tidak ada aktivitas, tanpa aktivitas maka proses belajar tidak dapat berlangsung dengan baik. Mengaktifkan siswa pada dasarnya adalah cara atau upaya mengoptimalkan kegiatan belajar (Sujana, 1989; Slameto, 2003; Mabroer, 2007) untuk menangkap isi dan pesan pembelajaran.

Aktivitas belajar penting dibangun dalam pembelajaran (Sembiring, 2021), makin aktif siswa secara intelektual, manual dan sosial, maka akan semakin banyak ranah pendidikan yang dikuasai (Emda, 2018). Jadi, aktivitas siswa dalam belajar menentukan pengalaman belajar yang akan diperolehnya. Oleh sebab itu, pembelajaran saat ini diutamakan pembelajaran berbasis aktivitas dengan materi sejarah lokal.

Efektivitas buku teks selanjutnya dilihat dari peningkatan kompetensi pengetahuan siswa (Prananda, M. N., Sarkadi, S., \& Ibrahim, 2018). Analisis data menunjukkan peningkatan pengetahuan siswa dengan menggunakan Buku Teks Sejarah Indonesia Bermuatan Sejarah Lokal Sumatera Barat untuk pembelajaran Sejarah Indonesia di SMA lebih tinggi dari pengetahuan hasil belajar dengan non buku teks bermuatan lokal. Selain itu buku teks juga melibatkan pengetahuan struktural (structural knowledge), meliputi jejaring, semantic mapping, peta konsep dan model mental. Pembelajaran dengan materi sejarah lokal memungkinkan siswa memperoleh pengalaman belajar pada level struktur pengetahuan yang lebih tinggi.

\section{Simpulan}

Berdasarkan hasil penelitian serta merujuk pada tujuan penelitian diperoleh kesimpulan bahwa Buku Teks Sejarah Indonesia Bermuatan Sejarah 
Lokal Sumatera Barat untuk pembelajaran Sejarah Indonesia di SMA yang valid, praktis dan efektif melalui tahap pengembangan Plomp .Buku dinyatakan valid oleh validator karena memiliki semua komponen buku teks. Isi buku dapat memenuhi tuntutan muatan lokal dalam pembelajaran Sejarah Indonesia di Sumatera Barat. Hal ini didukung oleh kuesioner yang diberikan kepada validator. Selain itu buku teks untuk pembelajaran Sejarah Indonesia di SMA tersebut juga terbukti efektif untuk meningkatkan kompetensi pengetahuan siswa.

\section{Daftar Rujukan}

Anrianti, R., Suri, S., \& Melay, R. (2013). Peranan Guru Sejarah Dalam Menumbuhkan Semangat Patriotisme Siswa dalam Mata Pelajaran Sejarah di kelas XI SMA N 2 Peranap Kecamatan Peranap Kabupaten Indragiri Hulu. Journal of Petrology, 369(1), 1689-1699.

http://dx.doi.org/10.1016/j.jsames.2011.03.003\%0Ahttps://doi.org/10.101 6/j.gr.2017.08.001\%0Ahttp://dx.doi.org/10.1016/j.precamres.2014.12.018\% 0Ahttp:/ / dx.doi.org/10.1016/j.precamres.2011.08.005\%0Ahttp:/ /dx.doi.or g/10.1080/00206814.2014.902757\%0Ahttp://dx

Asri, A. S. (2017). Telaah buku teks pegangan guru dan siswa pada mata pelajaran bahasa indonesia kelas VII berbasis kurikulum 2013. RETORIKA: Jurnal Ilmu Bahasa, 3(1), 70-82.

Atmaja, H. T. (2017). Reposisi Pembelajaran Sejarah Lokal dalam Menghadapi Era Global.

Casanova, G., Dadi, S., \& Lukman, L. (2018). Kemampuan Siswa Dalam Memahami Bahan Ajar Muatan Lokal Sejarah Kerajaan Bengkulu Di Kelas V Sekolah Dasar Negeri 25 Kota Bengkulu. JURIDIKDAS: Jurnal Riset Pendidikan Dasar, 1(2).

Dhita, A. N., Asmi, A. R., \& Yunani, Y. (2021). Nilai-Nilai Entrepreneur Pada Buku Teks Mata Pelajaran Sejarah dan Implementasinya di SMA Negeri 1 Indralaya. Jurnal Sejarah, Budaya, Dan Pengajarannya, 15(1), 62-73.

Emda, A. (2018). Kedudukan Motivasi Belajar Siswa Dalam Pembelajaran. Lantanida Journal, 5(2), 172.

Fajarini, U. (2014). Peranan Kearifan Lokal Dalam Pendidikan Karakter. SOSIO DIDAKTIKA: Social Science Education Journal, 1(2).

Hamalik, O. (2010). Pendidikan Guru Berdasarkan Pendekatan Kompetensi. Bumi Aksara.

Hardi, E. (2017). Pembelajaran Sejarah Bermuatan Lokal Pada Sekolah Menengah Atas (SMA) Di Sumatera Barat. Diakronika, 17(2), 153-162.

I Gde, W. (1991). Pendidikan Sejarah Dan Tantangan Masa Depan.

Jufri, D. (2016). Sudut Pandang Perencanaan dalam Pengembangan Pendidikan. Jurnal Inspirasi Pendidikan, 1(1), 65-76.

Nafi'ah, U., Ayundasari, L., Suprapta, B., Sayono, J., \& Hasan, Z. (2021). Tantangan Pengembangan Desain Pembelajaran Sejarah Lokal Berbasis 
Kehidupan di Masa Pandemi Covid 19. Jurnal Pendidikan Sejarah Indonesia, $4(2), 180-191$.

Naim, M. (2013). Merantau Pola Migrasi Suku Minangkabau Edisi Ketiga. Rajawali Perss.

Prananda, M. N., Sarkadi, S., \& Ibrahim, N. (2018). Efektivitas Sumber Pembelajaran Sejarah. Jurnal Pendidikan Sejarah, 7(2), 67-84.

Purwanto, Y. (2021). Analisis karakter nasionalisme dan toleransi pada buku teks sejarah kelas XI: membangun jati diri Indonesia. Historiography: Journal of Indonesian History and Education, 1(2), 115-123.

Rochmad. (2012). Desain Model Pengembangan Perangkat Pembelajaran Matematika. Kreano: Jurnal Matematika Kreatif-Inovatif, 3(1), 59-72.

Rochmiatun, E. (2013). Kedudukan Sejarah di Tengah Ilmu-Ilmu Lain. Tamaddun: Jurnal Kebudayaan Dan Sastra Islam, 13(1).

Sakkab, N. Y. (2002). Connect \& develop complements research \& develop at P\&G. Research-Technology Management, 45(2), 38-45\.

Salirawati, D. (2005). Persiapan Pembelajaran (Makalah). http://staff.uny.ac.id/sites/default/files/Persiapan Pembljr_0.doc

Sembiring, E. (2021). Tinjauan Aktivitas Belajar Siswa Dalam Meningkatkan Hasil Belajar Matematika Dengan Menggunakan Model Pembelajaran Kooperatif. UNIMED.

Soejatmoko. (1984). Dimensi Manusia Dalam Pembangunanx. LP3ES.

Subiyakto, B., \& Akmal, H. (2020). Profesi Keguruan. Program Studi Pendidikan Sejarah Fakultas Keguruan dan Ilmu Pendidikan ....

Supriatna, N. (2005). Konstruksi Pembelajaran Sejarah Lokal untuk Memahami Isu-isu Sosial. Historia: Jurnal Pendidikan Sejarah, 11, 113-133.

Suyitno, I. (2012). Pengembangan pendidikan karakter dan budaya bangsa berwawasan kearifan lokal. Jurnal Pendidikan Karakter, 1, 1-13.

Tinnisa, A. F. (2021). Penggunaan buku sejarah Indonesia dalam pembelajaran sejarah di SMA Brawijaya Smart School Malang. Universitas Negeri Malang.

Trianto, M. P. (2010). Pengantar Penelitian Pendidikan Bagi Pengembangan Profesi Pendidikan \& Tenaga Kependidikan. In Kencana, Jakarta. Kencana.

Trisanti, D. Y., \& Andayani, E. (2021). Pengaruh Metode Indexcard, Motivasi Belajar dan Penggunaan Media Film Terhadap Hasil Belajar Sejarah. Jurnal Penelitian Dan Pendidikan IPS, 15(2), 164-172.

Utomo, S. S. (2019). Guru Di Era Revolusi Industri 4.0. Format Pendidikan Untuk Meningkatkan Daya Saing Bangsa, 1(1), 70-83.

Wijayanti, Y. (2017). Peranan Penting Sejarah Lokal Dalam Kurikulum Di Sekolah Menengah Atas. Jurnal Artefak, 4(1), 53.

Wiyanarti, E., Supriatna, N., \& Winarti, M. (2020). Pengembangan Sejarah Lokal Sebagai Sumber Pembelajaran Sejarah Yang Kontekstual. FACTUM: Jurnal Sejarah Dan Pendidikan Sejarah, 9(1), 67-74.

Yamin, M. (2021). Analisis Buku Teks: Muatan Nilai Multikultural Dalam Buku Teks IPS Kelas VIII. Reform: Jurnal Pendidikan, Sosial, Dan Budaya, 4(1), 1-10. Zulfa, Z., \& Husnita, L. (2015). Analisis Kelengkapan Materi Buku Teks Sejarah Kelas XI yang Dipakai di Sekolah-Sekolah SMA di Kota Padang (Buku 
DIAKRONIKA 21 (2) 2021

ISSN: 1411-1764 (Print) | 2620-9446 (Online)

Erlangga, Platinum, Bumi Aksara, dan Yudistrira). Jurnal Pelangi, 7(2). 